\title{
Environmental tracers as a tool in groundwater vulnerability assessment
}

\section{Traccianti ambientali come strumento nella valutazione della vulnerabilità degli acquiferi}

Przemysław Wachniew

\begin{abstract}
Riassunto: I traccianti ambientali sono proprietà fisiche $\mathrm{e}$ componenti chimici dell'acqua la cui differenziazione spaziale e temporale è usata per ricavare informazioni sui percorsi e le dinamiche dell'acqua ed il movimento dei soluti attraverso l'ambiente. Ciò che si può ricavare in termini quantitativi e qualitativi in merito al funzionamento dei sistemi idrogeologici è utile per la valutazione fisicamente basata della vulnerabilità delle qualità delle acque sotterranee alla pressione antropica. Le informazioni ricavabili attraverso i traccianti possono permettere sia l'individuazione della connessione idraulica tra la sorgente di contaminazione ed il recettore acque sotterranee sia la valutazione della capacità delle zona insatura e dell'acquifero saturo di ritardare ed attenuare la diffusione dei contaminati. Particolarmente importante è la distribuzione dei tempi di transito delle acque che può essere ricavata dall'osservazione dei traccianti mediante l'uso di modelli del tipo a "lumped parameter". Le distribuzioni dei tempi di transito contengono informazioni sul tempo di ritardo, sull'attenuazione e sulla persistenza dei contaminanti nei sistemi idrogeologici, rappresentando una base per definire diversi indici di vulnerabilità. A fronte dei vantaggi dei traccianti ambientali nella valutazione della vulnerabilità e dei progressi nelle tecniche analitiche, l'applicazione dei traccianti in questo campo è limitato. Questo lavoro presenta lo stato dell'arte sui metodi usati per definite la vulnerabilità delle acque sotterranee nel contesto della valutazione del rischio, illustra i concetti di base dell'applicazione dei traccianti ambientali, discute la potenziale applicazione di traccianti per la valutazione della vulnerabilità intrinseca delle acque sotterranee e presenta alcuni esempi di queste applicazioni.
\end{abstract}

Parole chiave: acque sotterranee, vunerabilità, traccianti, isotopi.

Keywords: groundwater, vulnerability, tracers, isotopes.

Przemysław WACHNIEW 苇:

AGH University of Science and Technology

Mickiewicza 30, 30-059 Kraków, Poland,

wachniew@agh.edu.pl

Ricevuto: 12 marzo 2015 / Accettato: 18 maggio 2015

Pubblicato online: 30 giugno 2015

This is an open access article under the CC BY-NC-ND license: http://creativecommons.org/licenses/by-nc-nd/4.0/

(C) Associazione Acque Sotterranee 2015

\begin{abstract}
Environmental tracers are physical properties and chemical components of water whose spatial and temporal differentiation is used to infer information on the pathways and dynamics of water and solutes movement through the environment. The quantitative and qualitative insights into the functioning of groundwater systems derived from tracer observations is useful for the physically based and operational assessments of vulnerability of groundwater quality to buman pressures. This tracer-based information concerns identification of the bydraulic connections between the source areas of pollution and groundwater receptors and evaluation of the ability of the unsaturated and saturated zones to delay and attenuate spreading of pollutants. Particularly important are distributions of water transit times which can be inferred from tracer observations by use of the lumped parameter models. The transit time distributions contain information on the lag-times, attenuation and persistence of pollutants in groundwater systems and are a basis for designing various indexes of vulnerability. Despite the advantages of environmental tracers in vulnerability assessment and despite the advances in analytical techniques application of tracers in this field is limited. This work presents the understanding of groundwater vulnerability in the context of risk assessments, explains the basic concepts of the application of the environmental tracers, discusses potential applications of tracers in assessing the intrinsic groundwater vulnerability and briefly presents examples of such applications.
\end{abstract}

\section{Introduction}

Globally, groundwater resources are impacted by different human pressures, such as overexploitation, contamination, changes in land use and climate patterns. Maintaining the good chemical status of groundwater with respect to its use for human consumption but also with respect to the requirements of ecosystems dependent on groundwater is an important component of the sustainable development programmes. An indispensable element of the groundwater resources management are predictions of the effects that the anthropogenic pressures exert on groundwater quality. The integrative approach of the Water Framework Directive (WFD) of the European Union towards maintaining the good status of the surface and groundwater bodies encompasses consideration of risks to groundwater users and to the environment caused by pollution and other anthropogenic pressures (Fig. 1). The groundwater bodies found to be at risk of failing to meet the environmental objectives for groundwater set out by the WFD are subject to detailed risk assessments, a crucial component of which is evaluation of their vulnerability to pollution (EC 2010). At the same time, implementation of these 
recommendations is hindered by lack of clear definitions and of commonly agreed procedures of vulnerability assessment.

Vulnerability can be assessed in relation to all potentially

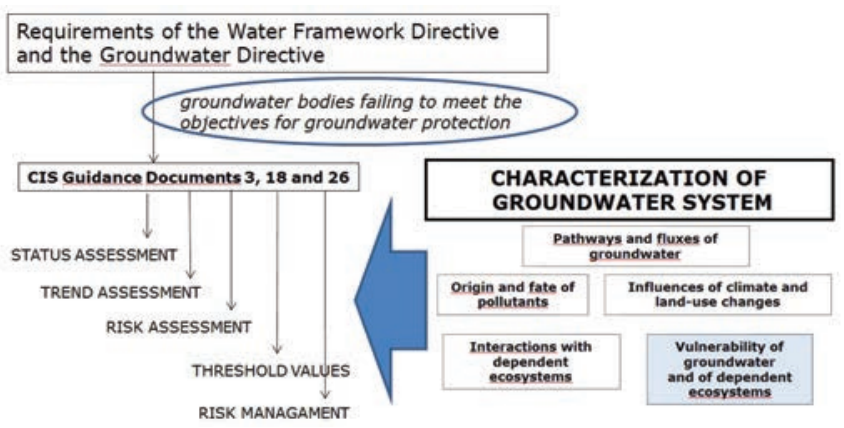

Fig. 1 - Groundwater vulnerability assessment as an element in the characterization of groundwater system functioning. The Common Implementation Strategy Guidance Documents 3, 18 and 26 (EC 2003; EC 2009; EC 2010) provide practical guidance on the analysis of pressures, impacts and risks for groundwater bodies.

Fig. 1 - La valutazione della vulnerabilità delle acque sotterranee quale elemento per la caratterizzazione del funzionamento dei sistemi idrogeologici I Documenti Guida 3, 18 e 26 della Strategia Comune di Attuazione (CE 2003 CE 2009; CE 2010) forniscono una guida operativa per l'analisi di pressioni, impatti e rischi per i corpi idrici sotterranei

adverse effects of human activities on the environment in general, particularly those associated with the climatic change (Eakin and Luers 2006; Kelly and Adger 2000). However, despite - or maybe because of - the popularity of this term in the scientific and environmental policy literature there exist a multitude of its definitions. Many of these formulations are ambiguous and not logically rigorous hindering a common understanding of vulnerability and the possibility of its operational application (Hinkel 2011). A similar ambiguity affects the usefulness of groundwater vulnerability assessments (Daly et al. 2002; Frind et al. 2006). In spite of these difficulties the vulnerability assessments have become a common element of groundwater resources management, particularly when their results are expressed in form of maps. The most popular approaches to vulnerability mapping, e.g. DRASTIC, belong to the category of the subjective methods where the indexes of vulnerability are composed through the subjective rating of the significance of the presumed vulnerability factors. While being flexible and relatively easy to apply these methods have serious drawbacks. Their subjectivity precludes comparisons between different cases. Lack of quantitative links between the obtained vulnerability indicators and the physical processes that govern spreading of contaminants prevents the meaningful comparisons and validation of such assessments (Neukum and Hotzl 2007; Neukum et al. 2008). There is therefore an obvious need for the physically based and scientifically rigorous but at the same time operational methods of assessing groundwater vulnerability.

Regardless of the terminological confusion, groundwater vulnerability can be understood within the framework of the Source-Pathway-Receptor (SPR) paradigm of risk assessments, according to which conceptual models of casual links between sources of contamination and the potentially affected groundwater receptors (production wells, groundwater dependent ecosystems) are built. Such models need to address patterns of groundwater flow, its temporal dynamics and contaminant behavior in the subsurface. The levels and temporal characteristics of contaminant occurrence at a receptor depend on the structure of groundwater flow paths and on the extent of contaminant dilution and dispersion in the geological medium and of contaminant attenuation due to its retardation and decay. The pathway component of the SPR paradigm determines groundwater vulnerability whose assessment may be limited to the characteristics of groundwater movement and mixing (intrinsic vulnerability) or may include attenuation characteristics of a particular contaminant (specific vulnerability). Consequently, the physically based approaches to the vulnerability assessment have to consider all processes governing groundwater flow and contaminant transport, also in their non-steady state aspects. Basically, this requirement can be fulfilled by numerical modeling of flow and transport provided that a properly validated model exist for the groundwater system of interest. Besides approaches to assessing the intrinsic vulnerability based on numerical modelling (Beaujean et al. 2014), successful attempts have been made to relate vulnerability indicators to the time required by water to reach groundwater tables or groundwater receptors (Daly et al. 2002; Herman et al. 2009; Witczak et al. 2007). In simple cases, the timescale of water flow can be evaluated as the turnover time of water or by application of Darcy's law. More comprehensive estimates are provided by application of environmental tracers (Cook and Böhlke 2000; Eberts et al. 2012; Jurgens et al. 2014; Visser et al. 2013). Nevertheless, the potential of the environmental tracers for use in groundwater vulnerability assessments is not widely recognized. Used commonly in hydrogeology to date groundwater or to calibrate the numerical models of groundwater flow and transport, the environmental tracers can provide information on the pathways and time scales of groundwater and contaminant movement as well as on transformations of the reactive contaminants. As such they can provide a basis for designing various indexes of the intrinsic and specific vulnerability. This paper discusses the actual and potential applications of environmental tracers in the physically based assessments of groundwater vulnerability with an emphasis on the intrinsic vulnerability.

\section{Environmental tracers - Principles of application}

Environmental tracers used in hydrology and hydrogeology can be defined as physical properties and chemical components of water whose spatial and temporal differentiation is used to infer information on the pathways and dynamics of water and solutes movement through the environment. This broad definition encompasses both the isotopic tracers whose application might require application of sophisticated and costly analytical methods and the easy to determine in the field properties of water such as temperature or electric conductivity. Many of environmental tracers are substances 
that were released as a result of human activities but are so ubiquitous in the hydrosphere and the atmosphere that they have already become inherent components of the global hydrological cycle.

The basic concept of tracer application is that within the bulk of water or of solutes present in the studied system some portions of these substances can be distinguished by their characteristic tracer signatures (concentration, isotopic composition). A prerequisite for application of tracers is that the spatial or temporal differentiation of tracer signatures exceeds the sampling and analytical precisions. These differentiated isotopic signatures can be inherited from the infiltrating water or acquired during passage of water through soils and rocks where the composition of dissolved substances is formed. Concentrations of tracers in groundwater may vary with time due to variable inputs or because they are subject to the radioactive decay. Such tracers can be used to derive the age of groundwater. However, the simplest mode of tracer application is purely qualitative and relies on a simple comparison of the isotopic signatures between different parts of the groundwater system or between groundwater and infiltrating water. Such comparisons can provide information on the internal structure of the system or on the presence or lack of hydraulic connections between its parts, e.g. between the recharge and discharge areas which is a basic factor in the vulnerability assessments.

In the quantitative mode, tracers can be used to derive time scales of water flow, estimate the relative contributions of different flow components at the groundwater receptor or characterize aquifer properties. The quantitative interpretation of tracer data requires application of the mathematical models describing how tracer signatures change along the groundwater flowpaths due to mixing, dispersion and removal processes. Fitting of the tracer data to such models provides quantitative characteristics of flow velocity, groundwater volumes and hydrodynamic dispersion. Below are briefly described applications of the most common tracers (see also Table 1.). The details of the use of the environmental tracers in hydrology and hydrogeology are presented in several handbooks (Clark and Fritz 1997; Cook and Herczeg 2000; Gat 2010; Kazemi et al. 2006; Kendall and McDonnell 2012; Leibundgut et al. 2009; Mook 2001). Methods for dating of young groundwaters with the environmental tracers are discussed by Newman et al. (2010).

\section{Stable isotope composition of water}

Stable isotopic signatures of water expressed as $\delta^{18} \mathrm{O}$ and $\delta^{2} \mathrm{H}(\delta \mathrm{D})$ are the most commonly used environmental tracers due to their wide applicability, easy sampling procedures and moderate costs of analyses. The "delta" notation is a way to express the relative abundances of the oxygen $\left({ }^{16} \mathrm{O},{ }^{18} \mathrm{O}\right)$ and hydrogen $\left({ }^{1} \mathrm{H},{ }^{2} \mathrm{H}\right)$ isotopes in water molecules. The differentiation of the stable isotopes of water in the hydrological cycle arises in two stages. Firstly, the spatial and temporal differentiation of atmospheric precipitation is driven by rainout processes. Isotopic composition of precipitation depends generally on air temperature through the so called seasonal, altitude, latitude and continental effects. Secondly, evaporation from the surface water bodies and from the ground shifts isotopic signatures of infiltrating water towards higher delta values.

The resulting spatial and temporal (mainly seasonal) differentiation in isotopic composition of infiltrating water provides a basis to infer pathways and timescales of groundwater flow. Typical applications of this isotopic differentiation are related to identification and delineation of recharge zones and to identification and quantification of mixing between isotopically different parts of groundwater systems, including surface water bodies. Temporal differentiation of stable isotopic composition in infiltrating or recharging water is used to derive timescales of flow and the values of transport parameters (i.e. dispersivities) in the unsaturated, and even the saturated zone.

Tab. 1 - Typical applications in hydrogeology of the most commonly used environmental tracers.

Tab. 1 Applicazioni tipiche in idrogeologia dei traccianti ambientali più comunemente usati.

\begin{tabular}{|l|l|}
\hline Tracer & Typical applications \\
\hline$\delta^{18} \mathrm{O}, \delta^{2} \mathrm{H}\left(\mathrm{H}_{2} \mathrm{O}\right)$ & $\begin{array}{l}\text { Origin and mixing of waters; residence } \\
\text { time of water in the unsaturated zone and } \\
\text { small catchments; estimation of recharge } \\
\text { rates }\end{array}$ \\
\hline${ }^{3} \mathrm{H}$ & $\begin{array}{l}\text { Identification and dating of young } \\
\text { groundwaters; estimation of recharge } \\
\text { rates }\end{array}$ \\
\hline Freon, $\mathrm{SF}_{6}$ & $\begin{array}{l}\text { Identification and dating of young } \\
\text { groundwaters }\end{array}$ \\
\hline${ }^{14} \mathrm{C}$ & $\begin{array}{l}\text { Discrimination between young and older } \\
\text { groundwater }\end{array}$ \\
\hline Water temperature & $\begin{array}{l}\text { Quantification of groundwater-surface } \\
\text { water exchange }\end{array}$ \\
\hline${ }^{222} \mathrm{Rn}$ & $\begin{array}{l}\text { Identification of groundwater outflows to } \\
\text { surface water bodies }\end{array}$ \\
\hline$\delta^{18} \mathrm{O}, \delta^{15} \mathrm{~N}\left(\mathrm{NO}_{3}{ }^{-}\right)$ & $\begin{array}{l}\text { Identification of sources; evidence for } \\
\text { denitrification }\end{array}$ \\
\hline organic compounds) & $\begin{array}{l}\text { Identification of sources; characterization } \\
\text { of degradation processes }\end{array}$ \\
\hline
\end{tabular}

\section{Tritium}

Tritium is a radioactive isotope of hydrogen (half-life of 12.32 years) naturally produced in the atmosphere by cosmic radiation. Airborne tritium is incorporated in water molecules in the atmosphere and enters the hydrological cycle. The occurrence of natural tritium in precipitation might be potentially used to date young (up to several decades) groundwater basing on the decrease of tritium activities with time due to radioactive decay. Such an obvious dating application is for the time being practically obstructed by the presence of anthropogenic tritium released by nuclear weapons test- 
ing in the atmosphere that peaked in the early 1960's. Lack of detectable tritium in groundwater shows that it is derived exclusively from infiltration that occurred before the commencement of nuclear weapons testing in 1952. On the other hand, the detectable occurrence of tritium does not exclude contribution of older infiltration as mixing between tritiumfree pre-bomb and recently recharged tritium-containing groundwaters might produce arbitrary low tritium concentrations. Time series of tritium concentrations spanning at least several years are used for groundwater dating. In this approach the distinct peak of bomb tritium in precipitation is traced through the groundwater system and its delay, dispersion and mixing with tritium-free water is mathematically modelled by use of lumped parameter (box) models (Maloszewski and Zuber 1993) that provide synthetic characterization of the flow system through transit time distributions. Application of these dating methods requires knowledge of time series of tritium in infiltration (tritium input function) which can be constructed (Maloszewski and Zuber 2001) on the basis of GNIP records of tritium activity in precipitation (http://iaea.org).

\section{Anthropogenic gases}

Similarly to tritium, atmospheric concentrations of gaseous substances of anthropogenic origin like freons, $\mathrm{SF}_{6}$ and ${ }^{85} \mathrm{Kr}$ have been changing significantly since the 1950's but in contrary to tritium they have none or only minor natural sources. Time-series of the atmospheric concentrations of these tracers are well-known. Applications, like for tritium, are twofold: (i) differentiation of waters recharged before and after introduction of these gases into the atmosphere, (ii) groundwater dating based on the known input functions of tracers. Unlike tritium, these tracers equilibrate with groundwater at its table, therefore they do not represent percolation through the unsaturated zone.

The above discussed tracers are used to infer knowledge on the pathways and timescales of groundwater flow. As such they are potentially useful in assessment of the intrinsic groundwater vulnerability. It should be however mentioned that in aquifers with significant fraction of immobile water the movement of tracers is delayed due to the diffusive exchange between the mobile and immobile zones (Maloszewski et al. 2004; Zuber et al. 2011). This phenomenon affects assessments of timescales of contaminant transport as the applied tracer and various contaminants can have considerably different diffusive properties.

The environmental tracers can be also used for assessing the specific groundwater vulnerability. Information on the sources and transformations of the organic and inorganic contaminants containing carbon, nitrogen and sulphur is provided by the stable isotope systematics of these elements. For example, stable isotope compositions of carbon and nitrogen are used to identify and characterize sources and transformations of organic pollutants (Nijenhuis et al. 2013) and nitrates (Kendall and Aravena 2000) in groundwater. Particularly, the compound specific stable isotopic analysis is applied in studies of pollutant degradation (Aelion et al. 2009; Hunkeler 2008).

Table 1 sums up typical applications of the most commonly used environmental tracers in characterization of groundwater flow patterns and of contaminants behaviour. These applications are meaningful in the context of the intrinsic vulnerability assessments as discussed in the following chapter.

\section{Environmental tracers in vulnerability assessments}

Application of environmental tracers can be considered as a scientific experiment conducted to test a hypothesis on the functioning of a hydrogeological system. Within the context of vulnerability assessments such hypotheses are formulated as conceptual models of contaminant spreading built according to the Source-Pathway-Receptor paradigm or as more complex numerical models (EC 2010). Regardless of the level of their complexity and detail the conceptual or numerical models describe the links between sources of contamination and groundwater receptors and the ability of the unsaturated and saturated groundwater zones to attenuate and delay contaminant arrival to the receptors. The environmental tracers provide valuable information for verification of such models leading to the better understanding of groundwater systems and to the more comprehensive models. Some kinds of information derived from tracer observations are relevant specifically to assessments of the intrinsic groundwater vulnerability. Two crucial questions of vulnerability assessments can be addressed with the use of tracers. First of them is the existence of the hydraulic connection between the actual or potential source areas of contamination and groundwater receptors whose vulnerability is assessed. Examples of such applications are identification of recharge areas and groundwater pathways or delineation of well capture zones. The second question of the intrinsic vulnerability are the timescales of groundwater flow and the ability of the unsaturated and saturated zones to dilute and delay solutes through mixing of different water components, hydrodynamic dispersion and exchange with immobile water. When the hydraulic connection with the source areas of contamination is confirmed the next factor in vulnerability assessment is evaluation of the time it takes for contaminated water to reach the receptors. Such information is derived from tracer observations by use of lumped parameter models (Eberts et al. 2012; Maloszewski et al. 2004; Maloszewski and Zuber 1993; Richter et al. 1993) and expressed as a mean transit time of groundwater from the recharge area to the receptor (groundwater age at the receptor) or as a probability distribution of transit times (ages). The lumped parameter models applied to tracer data allow also for identification and quantification of the multiple flow components. The information contained in the transit time distributions, such as the first arrival times of tracer, relative contributions of particular flow components and tracer persistence in the system are crucial for assessing the intrinsic vulnerability (Eberts, et al. 2012). The mean transit time of water is an obvious indicator of the intrinsic vulnerability as short (up to few tens of years) transit time suggest vulnerability to the industrial era pollution. For example, a single measurement 
showing presence of tritium or of the anthropogenic gaseous tracers in points of discharge indicates that the groundwater receptor is vulnerable to recent pollution. Given that groundwater at the receptor can be a mixture of fractions with a wide range of ages the mean age may not properly reflect the vulnerability characteristics, particularly in complex flow systems or in system with a large immobile water component. In such cases the full transit time distributions provide a basis for designing various vulnerability indexes (Neukum and Azzam 2009; Zwahlen 2004).

The information provided by tracers is usually contextual and case-specific. Therefore, generalization of environmental tracer methods is difficult and their application must be based on the thorough understanding of their principles. However, among the large body of literature on the use of environmental tracers in hydrogeology relatively few texts discuss the obtained results in the context of vulnerability. Below, several representative examples are briefly presented to provide a general overview of the environmental tracer applications in the intrinsic vulnerability assessments. These well-documented cases can provide guidance in all applications of tracers discussed above both in the qualitative (first two examples) and quantitative mode. Dimitriou and Zacharias (2006) surveyed stable isotope composition of water in a lake catchment with a complex hydrogeology. The differentiation of the isotopic signatures of springs, streams and lakes caused by the altitude effect and evaporation from surface water bodies allowed for linking the recharge and discharge areas, which improved the understanding of groundwater flow patterns. Andreo et al. (2006) confirmed rapid responses of karstic springs to rainfall events, and thus their high vulnerability, by comparing stable isotopic composition of precipitation and spring water during such events. Hunt et al. (2005) used stable isotopes of water for identifying contribution of surface water, whose isotopic composition is modified by evaporation comparing to local precipitation and groundwater, in a group of municipal supply wells. Furthermore, the temporal variations of the isotopic composition of groundwater in wells impacted by surface water were used to estimate transit times of surface water to wells during flood and non-flood conditions. Stichler et al. (2008) combined numerical modelling with stable isotope observations to delineate groundwater flow paths and capture zones for a drinking water supply threatened by infiltration from a recreational lake. The numerical model calibrated with groundwater head data could not identify the capture zone uniquely while use of the time series of the isotopic composition of lake water and groundwater constrained model results and allowed for estimation of proportions of lake water in wells and of hydraulic conductivity in the vicinity of the lake. The thus obtained information on the hydrodynamic field was significant for assessing vulnerability of the aquifer. Rapti-Caputo and Martinelli (2009) identified vulnerability for the heavily impacted unconfined and confined aquifers of the Po River plain through the integration of stratigraphical, hydrogeological, hydrochemical and isotopic (stable isotopes of water, tritium) data. The isotopic data indicated partial separation of the two aquifers and helped to identify their recharge areas as well as water transit times pointing to the most vulnerable parts of the system. Einsiedl et al. (2009) used stable isotopes of water and tritium to determine the origin and transit times of water in karstic springs indicating their low vulnerability to pollution related to the small contribution of the fast flow component and the relatively large mean transit time of water through the system. Sadek and El-Samie (2014) combined the hydrochemical and isotopic observations for assessing vulnerability of a shallow, heavily impacted aquifer using stable isotopes of water to identify origin of groundwater and tritium to estimate groundwater transit times in two parts of the aquifer characterized by different isotopic signatures. One of these areas revealed higher contribution of recent infiltration and thus higher vulnerability to anthropogenic pollution.

\section{Summary}

The environmental tracers have an important role in the validation and development of conceptual models built to assess human-induced risks to groundwater quality as required by the environmental policies and legislation. An advantage of the tracer methods, compared to the more traditional methods used in hydrogeology, lies in their ability to convey a synthetic information on groundwater system functioning integrated over a wide range of spatial and temporal scales. On the other hand, tracer methods work best when complemented by the hydrodynamic and hydrochemical observations and models. Tracer applications in the assessments of the intrinsic groundwater vulnerability are twofold: (i) identification of the groundwater flow paths converging in a receptor (ii) quantification of the timescales of contaminant transport and of contaminant attenuation due to the hydraulic processes. Concerning the latter, tracers can give not only values of mean transit times of water to the receptors but also transit times distributions which provide a comprehensive information on the lag-times, attenuation and persistence of contaminants in the groundwater system. Derivation of the transit time distribution from tracer observations can be performed by application of the lumped parameter models. Usefulness of the environmental tracers in vulnerability assessments is related not only to their ability to provide the physically based and operational indexes of vulnerability. They are also used for validation of other approaches to vulnerability assessment: of the subjective mapping methods and of the numerical models of flow and transport.

Tracer methods deserve to become a standard element of the vulnerability assessments because they provide information on the very nature of the hydrogeological processes related to water flow and contaminant transport that is not accessible by application of other methods. Meanwhile, the examples of tracer applications in this field are relatively few and often limited to use of the stable isotopes of water and tritium. Recent developments in isotope ratio laser spectrometers will contribute to more frequent application of stable isotope techniques because these new analyzers are less expensive and 
more mobile than the traditionally used mass spectrometers. A wider application of environmental tracers in hydrogeology, including vulnerability assessments, might be achieved through dissemination of these techniques among groundwater practitioners, educators and policy makers.

Acknowledgement: The author thanks the organizers of the Flowpath 2014 conference for their kind invitation to present the talk on which this paper is based. This work was supported by the GENESIS project funded by the European Commission 7FP (project contract 226536).

\section{REFERENCES}

Aelion C.M., Höhener P., Hunkeler D., Aravena R. (2009). Environmental isotopes in biodegradation and bioremediation CRC Press.

Andreo B., Goldscheider N., Vadillo I., Vias J.M., Neukum C., Sinreich M., Jimenez P., Brechenmacher J., Carrasco F., Hotzl H., Perles M.J., Zwahlen F. (2006). Karst groundwater protection: First application of a Pan-European Approach to vulnerability, hazard and risk mapping in the Sierra de Libar (Southern Spain). Sci Total Environ 357:54-73. DOI: 10.1016/j.scitotenv.2005.05.019.

Beaujean J., Lemieux J.M., Dassargues A., Therrien R., Brouyere S. (2014). Physically Based Groundwater Vulnerability Assessment Using Sensitivity Analysis Methods. Groundwater 52:864-874. DOI: $10.1111 /$ gwat.12132.

Clark I.D., Fritz P. (1997). Environmental isotopes in hydrogeology CRC press.

Cook P.G., Böhlke J.-K. (2000). Determining timescales for groundwater flow and solute transport, Environmental tracers in subsurface hydrology, Springer. pp. 1-30.

Cook P.G., Herczeg A.L. (2000). Environmental tracers in subsurface hydrology Springer Science \& Business Media.

Daly D., Dassargues A., Drew D., Dunne S., Goldscheider N., Neale S., Popescu I.C., Zwahlen F. (2002). Main concepts of the "European approach" to karst-groundwater-vulnerability assessment and mapping. Hydrogeology Journal 10:340-345. DOI: 10.1007/ s10040-001-0185-1.

Dimitriou E., Zacharias I. (2006). Groundwater vulnerability and risk mapping in a geologically complex area by using stable isotopes, remote sensing and GIS techniques. Environmental Geology 51:309-323. DOI: 10.1007/s00254-006-0328-8.

Eakin H., Luers A.L. (2006). Assessing the vulnerability of social-environmental systems, Annual Review of Environment and Resources. pp. 365-394.
Eberts S.M., Bohlke J.K., Kauffman L.J., Jurgens B.C. (2012). Comparison of particle-tracking and lumped-parameter age-distribution models for evaluating vulnerability of production wells to contamination. Hydrogeology Journal 20:263-282. DOI: 10.1007/ s10040-011-0810-6.

EC (2003). Common Implementation Strategy for the Water Framework Directive. Analysis of Pressures and Impacts. Guidance document No. 3.

EC (2009). Common Implementation Strategy for the Water Framework Directive. Guidance on Groundwater Status and Trend Assessment. Guidance document No. 18.

EC (2010). Common Implementation Strategy for the Water Framework Directive. Guidance on Risk Assessment and the Use of Conceptual Models for Groundwater. Guidance document No. 26.

Einsiedl F., Maloszewski P., Stichler W. (2009). Multiple isotope approach to the determination of the natural attenuation potential of a high-alpine karst system. Journal of Hydrology 365:113-121. DOI: 10.1016/j.jhydrol.2008.11.042.

Frind E.O., Molson J.W., Rudolph D.L. (2006). Well vulnerability: A quantitative approach for source water protection. Ground Water 44:732-742. DOI: 10.1111/j.1745-6584.2006.00230.x.

Gat J.R. (2010). Isotope hydrology: a study of the water cycle World Scientific.

Herman E.K., Toran L., White W.B. (2009). Quantifying the place of karst aquifers in the groundwater to surface water continuum: A time series analysis study of storm behavior in Pennsylvania water resources. Journal of Hydrology 376:307-317. DOI: 10.1016/j. jhydrol.2009.07.043.

Hinkel J. (2011). "Indicators of vulnerability and adaptive capacity": Towards a clarification of the science-policy interface. Global Environmental Change-Human and Policy Dimensions 21:198-208. DOI: 10.1016/j.gloenvcha.2010.08.002.

Hunkeler D. (2008). A guide for assessing biodegradation and source identification of organic ground water contaminants using compound specific isotope analysis (CSIA) Office of Research and Development, National Risk Management Research Laboratory, US Environmental Protection Agency.

Hunt R.J., Coplen T.B., Haas N.L., Saad D.A., Borchardt M.A. (2005). Investigating surface water-well interaction using stable isotope ratios of water. Journal of Hydrology 302:154-172. DOI: 10.1016/j.jhydrol.2004.07.010.

Jurgens B.C., Bexfield L.M., Eberts S.M. (2014). A Ternary Age-Mixing Model to Explain Contaminant Occurrence in a Deep Supply Well. Groundwater 52:25-39. DOI: 10.1111/gwat.12170.

Kazemi G.A., Lehr J.H., Perrochet P. (2006). Groundwater age John Wiley \& Sons.

Kelly P.M., Adger W.N. (2000). Theory and practice in assessing vulnerability to climate change and facilitating adaptation. Climatic Change 47:325-352. DOI: 10.1023/a:1005627828199.

Kendall C., Aravena R. (2000). Nitrate isotopes in groundwater systems, Environmental tracers in subsurface hydrology, Springer. pp. 261-297.

Kendall C., McDonnell J.J. (2012). Isotope tracers in catchment hydrology Elsevier.

Leibundgut C., Maloszewski P., Külls C. (2009). Environmental tracers. Tracers in Hydrology:13-56.

Maloszewski P., Stichler W., Zuber A. (2004). Interpretation of environmental tracers in groundwater systems with stagnant water zones. Isotopes in Environmental and Health Studies 40:21-33. DOI: $10.1080 / 10256010310001645717$. 
Maloszewski P., Zuber A. (1993). Principles and practice of calibration and validation of mathematical models for the interpretation of environmental tracer data in aquifers. Advances in Water Resources 16:173-190. DOI: 10.1016/0309-1708(93)90036-f.

Maloszewski P., Zuber A. (2001). Manual on lumped parameter models used for the interpretation of environmental tracer data in groundwaters. Environmental isotopes in hydrological cycle-Principles and applications, N 39, vol. VI, UNESCO-IHP-V.

Mook W. (2001). Environmental Isotopes in the Hydrological Cycle: Principles and Applications. IHP TecDoc 39, UNESCO/IAEA Available online at: http://www. iaea. org/programmes/ripc/ih/volumes/volumes. htm.

Neukum C., Azzam R. (2009). Quantitative assessment of intrinsic groundwater vulnerability to contamination using numerical simulations. Science of the total environment 408:245-254.

Neukum C., Hotzl H. (2007). Standardization of vulnerability maps. Environmental Geology 51:689-694. DOI: 10.1007/s00254-0060380-4.

Neukum C., Hotzl H., Himmelsbach T. (2008). Validation of vulnerability mapping methods by field investigations and numerical modelling. Hydrogeology Journal 16:641-658. DOI: 10.1007/ s10040-007-0249-y.

Newman B.D., Osenbruck K., Aeschbach-Hertig W., Solomon D.K., Cook P., Rozanski K., Kipfer R. (2010). Dating of 'young' groundwaters using environmental tracers: advantages, applications, and research needs. Isotopes Environ Health Stud 46:259-78. DOI: 10.1080/10256016.2010.514339.

Nijenhuis I., Schmidt M., Pellegatti E., Paramatti E., Richnow H.H., Gargini A. (2013). A stable isotope approach for source apportionment of chlorinated ethene plumes at a complex multi-contamination events urban site. J Contam Hydrol 153:92-105.
Rapti-Caputo D., Martinelli G. (2009). The geochemical and isotopic composition of aquifer systems in the deltaic region of the Po River plain (northern Italy). Hydrogeology Journal 17:467-480. DOI: 10.1007/s10040-008-0370-6.

Richter J., Szymczak P., Abraham T., Jordan H. (1993). Use of combinations of lumped-parameter models to interret groundwater isotopic data. J Contam Hydrol 14:1-13. DOI: 10.1016/01697722(93)90038-t.

Sadek M., El-Samie A.S. (2014). Pollution vulnerability of the Quaternary aquifer near Cairo, Egypt, as indicated by isotopes and hydrochemistry. Hydrogeology Journal 9:273-281. DOI: 10.1007/ s100400100125

Stichler W., Maloszewski P., Bertleff B., Watzel R. (2008). Use of environmental isotopes to define the capture zone of a drinking water supply situated near a dredge lake. Journal of Hydrology 362:220233. DOI: 10.1016/j.jhydrol.2008.08.024.

Visser A., Broers H.P., Purtschert R., Sültenfuß J., Jonge M. (2013) Groundwater age distributions at a public drinking water supply well field derived from multiple age tracers $(85 \mathrm{Kr}, 3 \mathrm{H} / 3 \mathrm{He}$, and 39Ar). Water Resources Research 49:7778-7796.

Witczak S., Duda R., Zurek A. (2007). The Polish concept of groundwater vulnerability mapping. Groundwater Vulnerability Assessment and Mapping: IAH-Selected Papers 11:45.

Zuber A., Rozanski K., Kania J., Purtschert R. (2011). On some methodological problems in the use of environmental tracers to estimate hydrogeologic parameters and to calibrate flow and transport mod els. Hydrogeology Journal 19:53-69. DOI: 10.1007/s10040-010 $0655-4$.

Zwahlen F. (2004). Vulnerability and risk mapping for the protection of carbonate (karst) aquifers, final report (COST action 620). European Commission, Directorate-General XII Science. Research and Development, Brussels 297. 